\title{
Combined lipid, fatty acid and digestive tract content analyses: a penetrating approach to estimate feeding modes of Antarctic amphipods
}

Accepted: 7 May 2001 / Published online: 22 June 2001

(C) Springer-Verlag 2001

\begin{abstract}
Antarctic amphipods from the Weddell Sea and Bransfield Strait were collected to investigate the impact of various species and feeding types on lipid and fatty acid compositions. In combination with digestive tract content analyses, such information can help clarify the type of feeding mode of the various amphipod species. Micro- and macropredatory amphipod species had only small amounts of triacylglycerols as storage lipids, whereas the deposit-feeder Epimeria georgiana was rich in triacylglycerols $(55 \%$ of total lipids). The fatty acids 22:6(n-3), 20:5(n-3), 18:1(n-9) and 16:0 were major lipid components of most species. Ampelisca richardsoni, a suspension feeder, had a high amount of 18:4(n-3), a major component of cryptophytes and/or haptophytes, connected with feeding on sedimenting phytoplanktonic material and with a strong bentho-pelagic coupling. In Oradarea edentata, fragments of brown algae were found almost exclusively. The major fatty acid of the macroalgae, 20:4(n-6), replaced the 22:6(n-3) in the phospholipids and triacylglycerols of the amphipod. The sponge eater, Echiniphimedia hodgsoni, was rich in 16:1(n-7) and 18:1(n-7), suggesting that the unidentifiable organic matter was of diatom origin. Eusirus perdentatus, a typical predator, had high proportions of saturated and monounsaturated fatty acids, showing no specialisation in lipid and fatty acid composition. The fatty acid composition of Epimeria georgiana was similar to that of Eusirus perdentatus. However, high levels of triacylglycerols in Epimeria georgiana reflect periodical food plenty and starvation, due to its dependence on dead items. The fatty acid composition of the necrophage Waldeckia obesa was clearly different because of
\end{abstract}

M. Graeve ( $₫)$

Alfred-Wegener-Institut für Polar- und Meeresforschung,

Postfach 120161, 27515 Bremerhaven, Germany

E-mail: mgraeve@awi-bremerhaven.de

P. Dauby $\cdot$ Y. Scailteur

Royal Belgian Institute of Natural Sciences (RBINS),

Rue Vautier 29, 1000 Brussels, Belgium the predominance of $18: 1(n-9)$ ( $>40 \%$ of total fatty acids). This dominance is probably the result of feeding on highly degraded carrion-derived organic matter, which is the major food of $W$. obesa.

\section{Introduction}

In Antarctic benthic communities, the peracarid crustaceans and especially the Amphipoda are by far the most species-rich group and probably the most diversified with respect to lifestyles, trophic types, habitats and size spectra (De Broyer and Jazdzewski 1996). Despite their low relative biomass these crustaceans, especially the amphipods, constitute a significant group in terms of energy flux in the high-Antarctic shelf ecosystem. They are an important food source for many Antarctic demersal and benthic fishes (e.g. Olaso et al. 2000). A qualitative and quantitative characterisation of the trophic roles of amphipods and peracarids in general, at the level of the key species and of the whole taxocoenoses, could contribute significantly to a more accurate image of the trophic structure and fluxes in Antarctic benthic communities (Dauby et al., in press).

The ecofunctional and trophodynamic roles of Antarctic amphipods are still poorly known, despite the pioneering studies of Richardson (1977), Oliver and Slattery (1985), Slattery and Oliver (1986), Coleman (1989a, b, c, 1990a, b) and Klages and Gutt (1990a, b). The trophic types have been studied in less than $10 \%$ of amphipod species, with very few quantitative approaches so far (Dauby et al. 2001). For example, for the most important super-families of Antarctic amphipods (namely Eusiroidea and Lysianassoidea), the feeding type cannot often be deduced with certainty from the morphology of the feeding appendages.

The importance of lipid and fatty acid compositions as trophic markers has been demonstrated in various studies (Sargent and Whittle 1981; Graeve 1993; Graeve et al. 1994, 1997; Phleger et al. 1998). The advantage of 
applying lipid compositions to feeding studies is that trophic lipid markers integrate longer time periods than conventional methods. However, there is a lack of information on lipid compositions of Antarctic benthic amphipods. Most of the available literature covers lipid data of pelagic amphipods (e.g. Reinhardt and Van Vleet 1986; Hagen 1988; Phleger et al. 1998, 1999, 2000; Nelson et al. 2001). In our study, lipid and fatty acid compositions of various benthic amphipod species were analysed and compared with food preferences determined by digestive tract content analyses. The benefits of combining both methods to reveal feeding behaviour and food sources is highlighted.

\section{Materials and methods}

The benthic amphipods Oradarea edentata, Ampelisca richardsoni, Echiniphimedia hodgsoni, Eusirus perdentatus, Epimeria georgiana and Waldeckia obesa were caught in the southeastern Weddell Sea and the Antarctic Peninsula during the EASIZ II cruise with RV Polarstern (ANT XV/3, 13 January to 26 March 1998; Arntz and Gutt 1999). The animals were taken from various depths by different gear: box corer, Agassiz trawl, bottom trawl and TV grab. The different sampling sites are shown in Fig. 1. Immediately after sampling, individuals were sorted into species. Digestive tract content analyses were performed on specimens immediately preserved in $4 \%$ formaldehyde after sampling, or on freshly killed individuals. For observation of the feeding behaviour, specimens were kept for several days in aquaria (for details refer to Dauby et al. 2001, in press). The individuals dedicated to lipid analyses were transferred into glass vials containing dichloromethane:methanol $2: 1(\mathrm{v}: \mathrm{v})$ and stored at $-30^{\circ} \mathrm{C}$ until later analyses in the home laboratory.

\section{Digestive tract analyses}

Amphipods (17 individuals of $O$. edentata, 20 of $A$. richardsoni, 20 of Echiniphimedia hodgsoni, 19 of Eusirus predentatus, 31 of Epimeria georgiana and 30 of $W$. obesa) were dissected under the dissecting microscope (Leica MZ12), using forceps and scissors. The digestive tract was cut at the oesophagus level and extracted together with midgut glands from the body. The digestive tract was separated from the midgut glands, opened and the contents spread on a microscope slide. Different dyes (Serva blue G, Fuchsin,

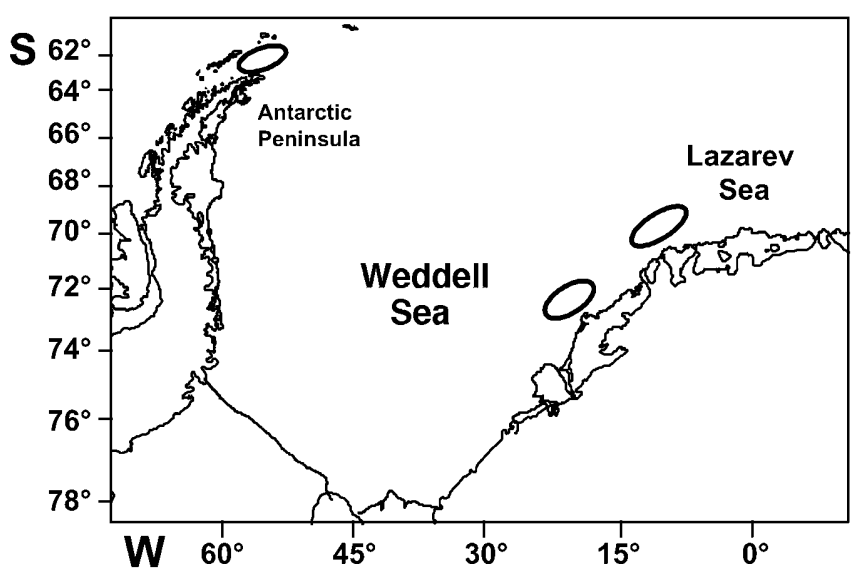

Fig. 1 Map and sampling locations of amphipods in Antarctica
Bengal pink) were added depending on the material to be detected. The whole slide surface was examined with a compound microscope (Leitz Diaplan) equipped with a reflection contrast system. Some digestive contents (or parts of them) were also metallised in order to be more closely examined by SEM techniques.

The amount of food in digestive tracts was coded using arbitrary scores (from 1 to 4 ). Every item present in the digestive tract was determined to the lowest possible taxonomic group, and their proportions coded using a semi-quantitative coefficient based on the "percentage points" method (Hynes 1950; Williams 1981). A detailed description of the method is given in Dauby et al. (2001, in press). In addition, observations of feeding and general behaviour were performed on species kept in aquaria at $-1^{\circ} \mathrm{C}$ (see Dauby et al. 2001, in press).

Lipid analyses

Twoxone adult animal of each species (max. size known: $O$. edentata, $11 \mathrm{~mm}$, A. richardsoni, $33 \mathrm{~mm}$, Echiniphimedia hodgsoni, $40 \mathrm{~mm}$, Eusirus predentatus, $87 \mathrm{~mm}$ Epimeria georgiana, $40 \mathrm{~mm}$, $W$. obesa, $35 \mathrm{~mm}$ ) were homogenised and total lipid extracted with dichloromethane:methanol $(2: 1 ; \mathrm{v}: \mathrm{v})$ according to Folch et al. (1957). The lipid class compositions were determined according to Fraser et al. (1985) by thin-layer chromatography-flame ionisation detection (TLC-FID) with an IATROSCAN Mark IV TH 10. Different standard mixtures of marine lipids were used for identification (Hagen 1988): wax esters derived from copepod oil, triacylglycerols derived from fish oil and commercial standards [cholesterol, oleic acid, phosphatidylcholine (Sigma)]. An aliquot of the extract was used to separate the lipid classes by preparative thin-layer chromatography with silica gel $60 \mathrm{H}$ (Merck) on $20 \times 20 \mathrm{~cm}$ glass plates. The bands were scraped off after visualising with a solution of $0.1 \%$ dichlorofluorescein in methanol, eluted in dichloromethane, evaporated to dryness and redissolved in hexane.

For the gas liquid chromatographic analysis of the fatty acids, aliquots of the total lipid extract and lipid classes were taken. Methyl esters of fatty acids were prepared by transesterification with $3 \%$ concentrated sulphuric acid in methanol for $4 \mathrm{~h}$ at $80^{\circ} \mathrm{C}$. After extraction with hexane, their composition was determined with a Chrompack 9000 gas liquid chromatograph on a capillary column $(30 \mathrm{~m} \times 0.25 \mathrm{~mm}$; film thickness $0.25 \mu \mathrm{m}$; liquid phase DBFFAP), using temperature programming according to the method of Kattner and Fricke (1986). Fatty acids were identified by comparison of the retention time with those of standard mixtures. If necessary, identification was confirmed by converting fatty acids into their DMOX derivatives (Fay and Richli 1991), which were analysed with a Hewlett-Packard GC-MSD System (Waldbronn) fitted with a capillary column similar to that already described.

\section{Results}

\section{Digestive tract contents}

The results of the digestive tract content analyses are presented in Fig. 2. O. edentata was feeding on macroalgae since pieces of macroalgae, probably Desmarestia sp. (Phaeophyta), were found exclusively in its digestive tract. The digestive tract of $A$. richardsoni contained many phytoplankton (diatom) fragments $(54 \%)$ embedded in unidentifiable organic matter $(36 \%)$ forming a kind of acellular mucus without structure. Other items were generally small and/or fragmented, partially sponge spicules $(7 \%)$. Some crustacean remains $(3 \%)$ were also identified. The digestive tract contents of Echiniphimedia hodgsoni consisted mainly of spicules of sponges $(61 \%)$. The remainder was phytoplankton- 
Fig. 2 Digestive tract content of amphipods. Distribution of individual food items as percentage of the total content ( $n$ number of studied animals)
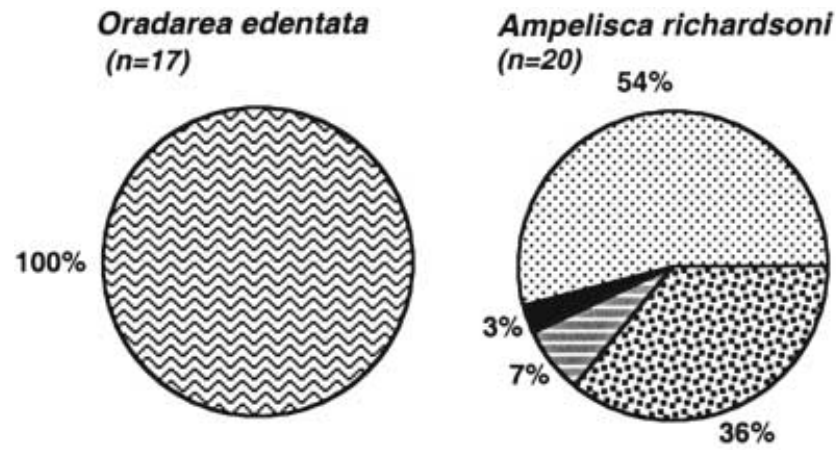

Echiniphimedia hodgsoni ( $n=20)$

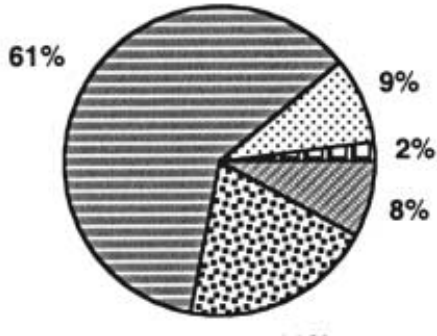

$20 \%$
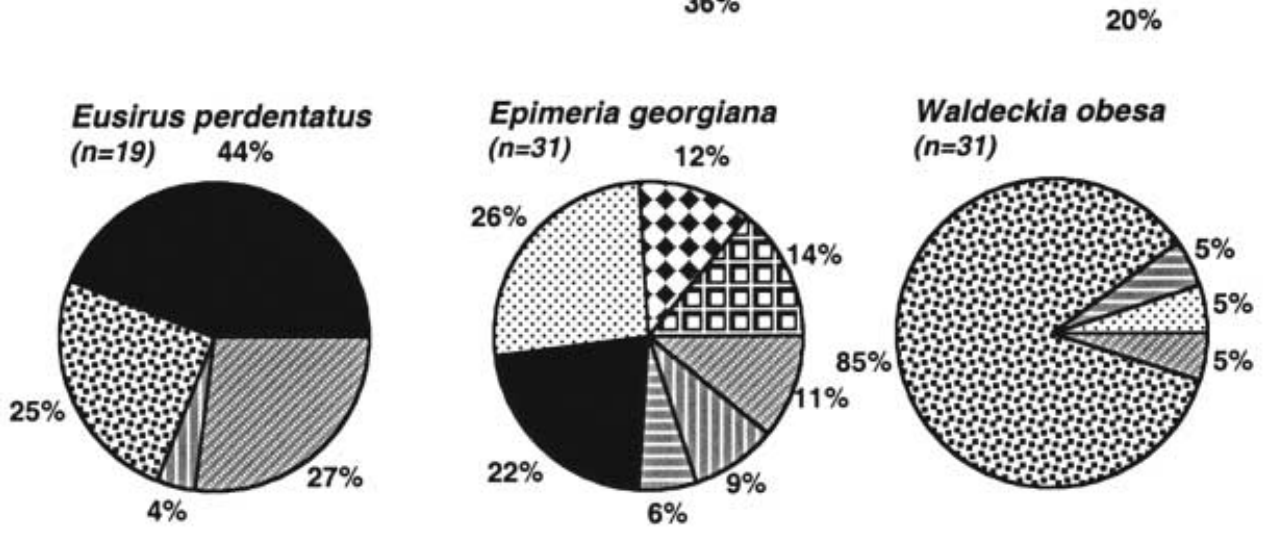

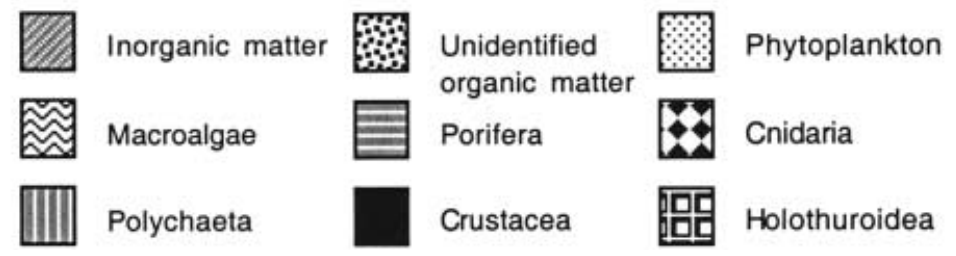

derived $(9 \%)$, Holothuroidea $(2 \%)$, unidentifiable organic matter $(20 \%)$ and some sediment grains $(8 \%)$. Eusirus perdentatus contained mostly crustacean remains $(44 \%)$, unidentified organic matter $(25 \%)$, mineral particles $(27 \%)$ and some polychaete setae $(4 \%)$ in its digestive tract. Items found in the digestive tract of Epimeria georgiana were very heterogeneous. The analyses exhibited remains of Crustacea $(22 \%)$, polychaetes $(9 \%)$, Holothuroidea (14\%), Cnidaria $(12 \%)$ and phytoplanktonic items $(26 \%)$. Sponge spicules $(6 \%)$ and mineral particles $(11 \%)$ completed the food. The digestive tract of $W$. obesa was almost exclusively filled with carrion-derived organic matter $(85 \%)$ originating from fishes, seabirds, cephalopods and benthic invertebrates. Other food items were plankton, inorganic matter and spicules, together composing $15 \%$ of the digestive tract contents.

Lipid and fatty acid composition

The lipid class and fatty acid compositions of total lipid extracts, triacylglycerols and phospholipids of amphipods revealed clear species-dependent differences. Major lipid classes were phospholipids and triacylglycerols. Sterols and other lipids occurred only in trace amounts (less than 1\%). Free fatty acids were not detected (Fig. 3).

In $O$. edentata, phospholipids and triacylglycerols accounted for $70 \%$ and $30 \%$ of total lipids, respectively (Fig. 3). One of the major fatty acids was 20:4(n-6), accounting for up to $20 \%$ of total fatty acids (Fig. 4). This fatty acid occurred in moderate amounts in Epimeria georgiana and only in trace amounts in the other amphipod species. Another major difference was the near absence of 22:6(n-3) in $O$. edentata. Other dominant fatty acids were 16:0, 18:1(n-9) and 20:5(n-3). Especially high quantities of 20:4(n-6) and 20:5(n-3) were found in the phospholipids, composing about $40 \%$ of the total. Moderate amounts $(11 \%)$ of $\mathrm{C}_{16}$ and $\mathrm{C}_{18}$ polyunsaturated fatty acids were detected in all lipid fractions (Fig. 4).

A. richardsoni had a higher level of triacylglycerols $(39 \%)$ than most of the other species (Fig. 3). The high amount of 18:4(n-3) in all lipid fractions, especially in the triacylglycerols $(25 \%)$, was striking. Other major fatty acids were 20:5(n-3), 22:6(n-3), 16:0 and 16:1(n-7). The proportions of $20: 5(n-3)$ and $22: 6(n-3)$ in the 
Fig. 3 Lipid class composition of amphipods as percentage of total lipid; PL: phospholipids, TAG: triacylglycerols

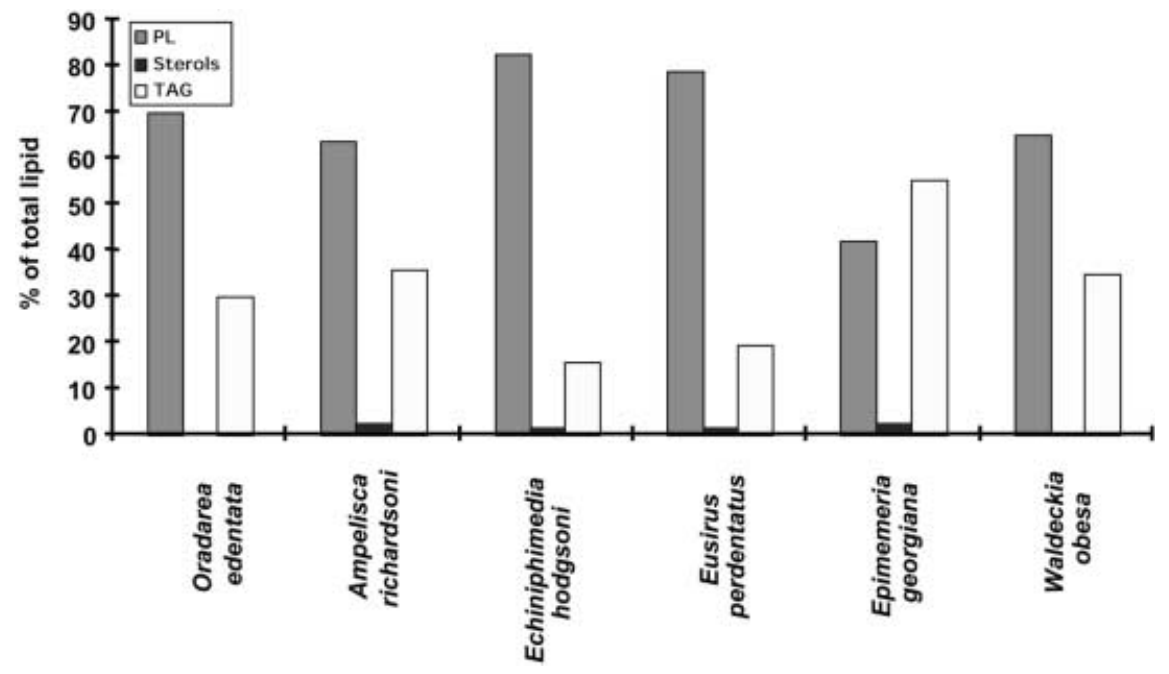

phospholipids ( $22 \%$ and $15 \%$, respectively) were slightly higher than in the triacylglycerols (Fig. 4). The ratio of 18:1(n-9)/18:1(n-7) was low (2.6).

The lipids of the sponge eater Echiniphimedia hodgsoni consisted mostly of phospholipids $(82 \%)$ and small amounts of triacylglycerols (16\%) (Fig. 3). The fatty acid composition of total lipids was dominated by $16: 0, \quad 16: 1(n-7), \quad 18: 1(n-9), \quad 18: 1(n-7)$ and 20:5(n-3) (Fig. 4). The proportions of polyunsaturated fatty acids with 16 and 18 carbon atoms were relatively low. 20:5(n-3) was dominant in the triacylglycerols, whereas 22:6(n-3) was detected in trace amounts in this lipid class. The phospholipids of Echiniphimedia hodgsoni showed high levels of 16:0, 18:1(n-9), 20:5(n-3) and 22:6(n-3). The elevated level of $18: 1(n-7)$ in all lipid fractions resulted in a low $18: 1(n-9) /(n-7)$ ratio (1.9).

The total lipids of Eusirus perdentatus were dominated by phospholipids (79\%) (Fig. 3). The fatty acids 16:0, 18:1(n-9), 20:5(n-3) and 22:6(n-3) were the major components in the total lipids and lipid classes (Fig. 5). The two polyunsaturated fatty acids had especially high proportions in the phospholipids. In the triacylglycerol fraction, 16:1(n-7) and 18:1(n-7) were slightly higher, composing $6 \%$ and $7 \%$, respectively.

Epimeria georgiana exhibited the largest portion of triacylglycerols of all amphipods, with $55 \%$ of the total lipids (Fig. 3). The fatty acid compositions were dominated by 16:0, 18:1(n-9), 20:5(n-3) and 22:6(n-3). Other important fatty acids were 16:1(n-7), 18:1(n-7) and 20:4(n-6). In the phospholipids, 16:0, 20:4(n-6), 20:5(n-3) and 22:6(n-3) occurred in higher proportions than in the triacylglycerols (Fig. 5).

$W$. obesa was also rich in triacylglycerols $(37 \%)$ (Fig. 3). Its fatty acid composition differed from all other species since 18:1(n-9) made up almost $50 \%$ of total fatty acids (Fig. 5). The fatty acid compositions of the triacylglycerols and phospholipids were very similar to that of the total lipids. Slightly enhanced levels of $20: 5(n-3)$ and 22:6(n-3) were found in the phospholipids. $W$. obesa had the highest $18: 1(n-9) /(n-7)$ ratio of all amphipods investigated, with 18.6 for triacylglycerols and 17.1 for phospholipids.

\section{Discussion}

Determination of lipid content and composition can improve interpretation of trophic interactions and pathways of organic material in the water column, as shown by Graeve et al. (1994) and Cripps and Hill (1998) for marine zooplankton. The trophic types of the species investigated here are described as herbivorous feeder (O. edentata), suspension feeder (A. richardsoni), micropredator (Echiniphimedia hodgsoni), macropredator (Eusirus perdentatus), deposit-feeder (Epimeria georgiana) and necrophage ( $W$. obesa) (Dauby et al., in press; Y. Scailteur, unpublished work). The lipid and fatty acid compositions of these Antarctic amphipods were characterised by distinct differences partially reflecting their different food preferences. High levels of storage lipids in only one species and moderate levels in two other species show that reliance on lipid reserves in the amphipods was generally low. This is in accordance with results reported for Arctic benthic amphipods (Graeve et al. 1997) and benthic amphipods from cold shallow waters (Kawashima et al. 1999).

Due to the usual dominance of phospholipids, the polyunsaturated fatty acids were abundant in most species, since they are typical for marine organisms and predominate among the membrane lipids (Sargent and Whittle 1981; Sargent and Henderson 1986; Albers et al. 1996). These polyunsaturates are normally $20: 5(n-3)$ and 22:6(n-3) in marine animals; however, in $O$. edentata 22:6(n-3) was absent and, in contrast, elevated levels of 20:4(n-6) were observed. Although in some species large amounts of the diet were of planktonic origin, we found no evidence for incorporation of long-chain monounsaturated fatty acids (20:1 and 22:1) from zooplankton such as herbivorous calanoid copepods. So far, this incorporation has only been observed for the lysianassoid 
Fig. 4 Fatty acid composition of the total lipid, triacylglycerols (TAG) and phospholipids (PL) of Oradarea edentata, Ampelisca richardsoni and Echiniphimedia hodgsoni as mass percent of total fatty acids
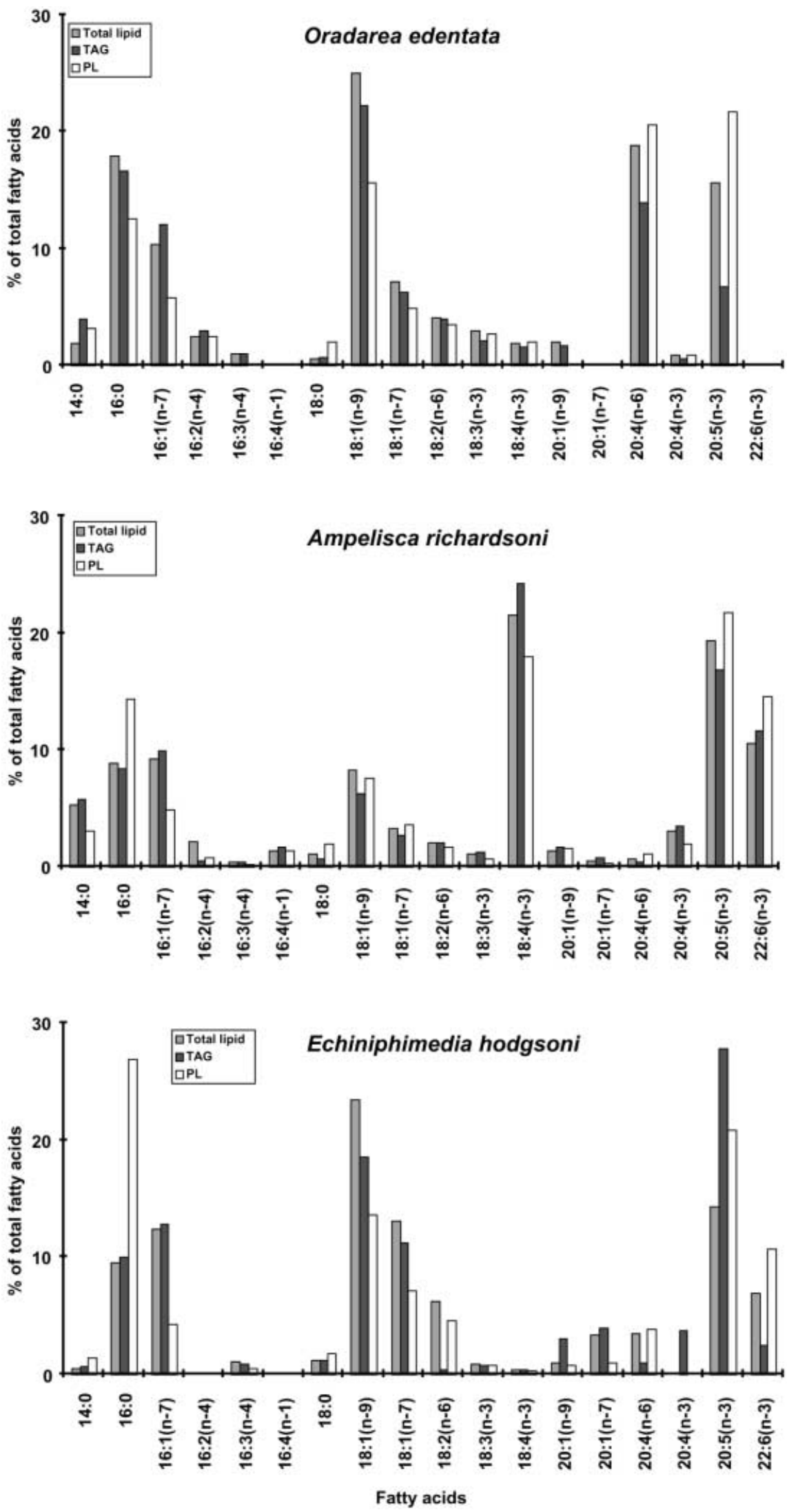
Fig. 5 Fatty acid composition of the total lipid, triacylglycerols and phospholipids of Eusirus perdentatus, Epimeria georgiana and Waldeckia obesa as mass percent of total fatty acids
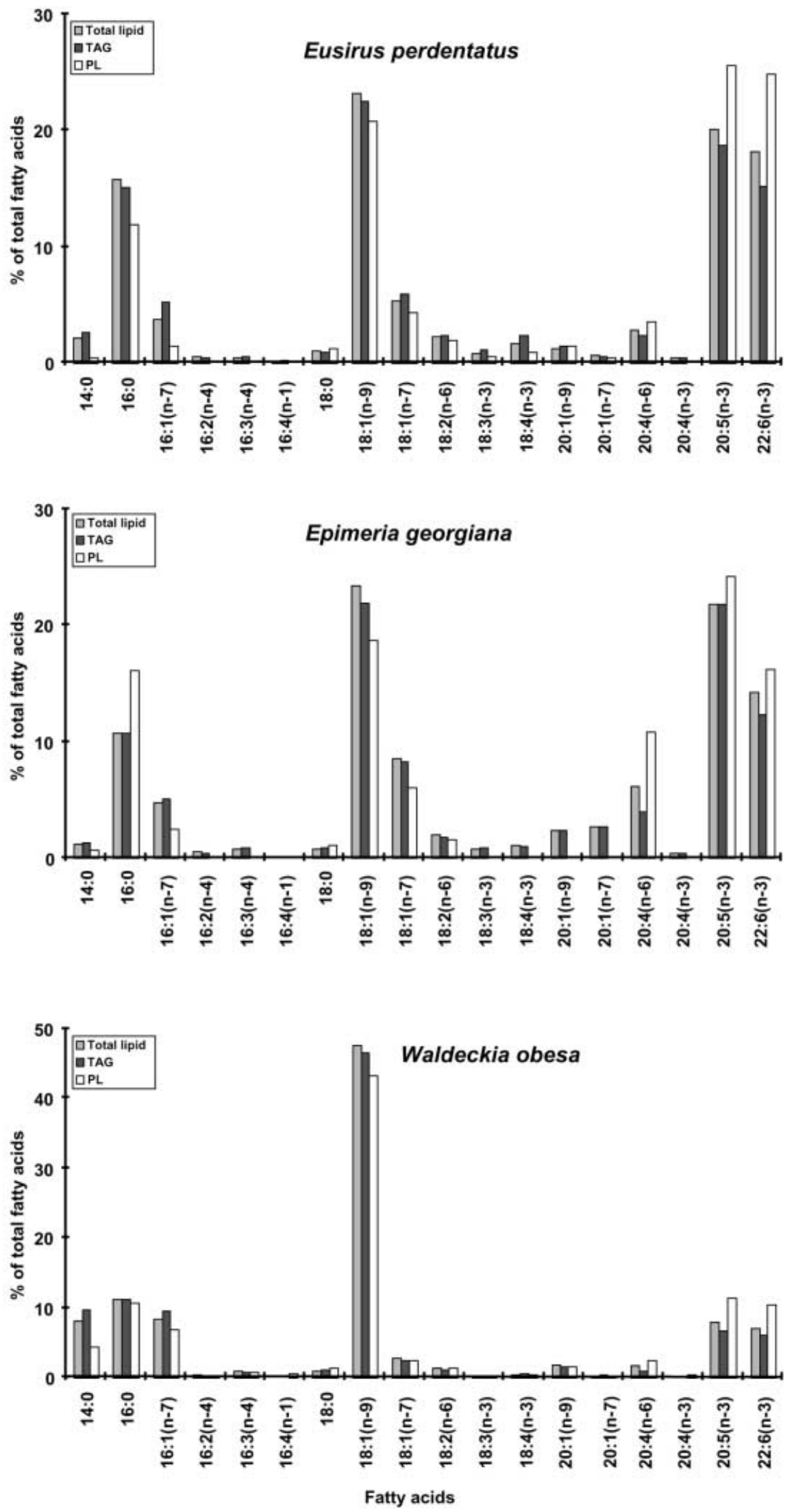
amphipod, Anonyx nugax, from the Arctic (Graeve et al. 1997). Also wax esters, the major storage lipids in most zooplankton species (e.g. Kattner and Hagen 1995), were not found in the Antarctic benthic amphipods, but small amounts were detected in the hyperiid amphipod, Primno macropa (Nelson et al. 2001). Thus, if amphipods are feeding on wax ester-rich organisms, these dietary lipids are not incorporated or utilised for metabolic requirements.

Among the investigated amphipods, the sublittoral herbivore $O$. edentata differs markedly from the other species examined in this and other studies due to its predominant feeding on macroalgae (Y. Scailteur, unpublished work). O. edentata contained only pieces of macroalgae, probably Desmarestia sp., in its digestive tract. Moderate amounts of triacylglycerols in the amphipod suggest that food is available year round. The most remarkable feature of this species is the high level of 20:4(n-6). This fatty acid certainly originates from macroalgae (M. Graeve, unpublished work) and is incorporated unmodified in the lipids of the amphipod. $20: 5(n-3)$ is another major fatty acid in macroalgae but 22:6(n-3) occurs only in trace amounts (Fleurence et al. 1994; Khotimchenko 1995). 20:4(n-6) has obviously replaced the 22:6(n-3) not only in the depot lipids but also in the phospholipids where it probably becomes part of the membrane structure. It is known that $(n-6)$ polyunsaturated fatty acids originate from benthic algae and some of the benthic invertebrates including molluscs, coelenterates, echinoderms and crustaceans contain substantial quantities of (n-6) polyunsaturated fatty acids, especially 20:4(n-6) (Sargent and Whittle 1981; Fleurence et al. 1994; Khotimchenko 1995; M. Graeve, unpublished work). In microalgae, especially Porphyrinium sp., Ackman et al. (1968) also found considerable amounts of 20:4(n-6), accounting for up to $25 \%$ of total fatty acids.

The epibenthic suspension feeder A. richardsoni is dependent on material sinking from the upper water column (Dauby et al. 2001). L.D. Gerdes (personal communication) found a large number of $A$. richardsoni specimens in corer samples from bottoms scoured by icebergs (mainly between 150 and $350 \mathrm{~m}$ ). This species may be an early coloniser of new soft substrates, feeding on organic material sedimenting rapidly to the bottom in shallow waters. The amount of triacylglycerols it contains reflects a moderate reliance on storage lipids, which may enable this species to survive periods of starvation. The digestive tract content of $A$. richardsoni was rich in diatom residues within organic material without any structure. The ingestion of diatoms is supported by the diatom marker fatty acids, 16:1(n-7) and 20:5(n-3) (Kates and Volcani 1966; Ackman et al. 1968; Graeve et al. 1994). However, the dominant fatty acid 18:4(n-3) points to the organic matter being largely of non-diatomous origin in which the diatom shells were embedded. Digestive tract analysis cannot differentiate the structureless mucus of organic matter, but 18:4(n-3) reflects feeding on material originating from phytoplankton, such as cryptophytes and/or haptophytes (Harrington et al. 1970; Nichols et al. 1991; Graeve 1993; Graeve et al. 1994; Swadling et al. 2000). 18:4(n-3) might be the signature of feeding on a decaying Phaeocystis bloom although 18:4(n-3) is not usually dominant in Antarctic Phaeocystis (Swadling et al. 2000). Those blooms are often observed in the Southern Ocean, and efficient sedimentation of Phaeocystis-derived organic matter has been described (Riebesell 1993; Wassmann 1994; Lancelot et al. 1998). Colonies or solitary cells of the haptophyte Phaeocystis pouchetii are ingested by a wide range of marine invertebrates (Weisse et al. 1994). The combination of digestive tract and fatty acid analyses reveals a strong bentho-pelagic coupling, indicating that A. richardsoni feeds mostly on phytoplankton-derived material. However, it must be remembered that blooms are short-term events and that the resulting fatty acid signature may vary with the dominating phytoplankton species.

Echiniphimedia hodgsoni is a large micropredator which principally feeds on sponge material. Feeding on sponges is possible due to the functional morphology of its mouth parts. With a special cutting mechanism, Echiniphimedia hodgsoni is able to bite out tough sponge material (Coleman 1989a). Since sponges are very common on the Antarctic shelf, this species does not rely on storage lipids, as reflected by its low triacylglycerol content. In sponges a wide range of unusual fatty acids has been described, including even-chain, odd-chain and branched-chain fatty acids, as well as very long-chain fatty acids (Carballeira and Reyes 1990; Dembitsky et al. 1994; Carballeira and Shalabi 1995). These unusual fatty acids were not detected in Echiniphimedia hodgsoni. However, the remaining digestive tract content, which could only be described as unidentifiable organic matter, may be assigned to a diatom origin on the basis of the considerable amounts of 16:1(n-7) and 18:1(n-7) in the animal. These fatty acids are indicative of diatom-derived particulate organic matter, which may originate directly from diatoms or from prey organisms feeding on diatoms. This is also supported by a higher 20:5/22:6 ratio. Slightly higher levels of 20:1 fatty acids may suggest feeding on copepods (Graeve et al. 1994; Phleger et al. 1998).

In contrast to these amphipods, Eusirus perdentatus is a macropredatory carnivorous species, which was observed feeding mainly on living crustaceans, polychaetes and other mobile invertebrates (Klages and Gutt 1990a). Although Eusirus perdentatus is a passive sit-and-wait predator, it seems to catch or find sufficient prey to be almost independent of lipid deposits, as shown by its relatively small proportions of triacylglycerols compared to the other species. In consequence, the typical membrane polyunsaturated fatty acids were dominant. This species shows no specialisation either in lipid or fatty acid compositions, which demonstrates a strongly opportunistic feeding behaviour.

The fatty acid composition of Epimeria georgiana is very similar to that of Eusirus perdentatus, although it 
prefers dead instead of living food items (Dauby et al. 2001). Epimeria georgiana is also a weakly mobile deposit-feeder. The heterogeneous digestive tract contents (fragments of crustaceans, polychaetes and cnidarians, but also diatoms and radiolarians) reflect a very diverse feeding behaviour. The ever-present sand grains confirm deposit-feeding. Compared to the other amphipods, Epimeria georgiana was rich in triacylglycerols, which may enable this species to compensate for longer periods of food scarcity. The reliance on dead food items may result in longer periods of starvation compared to predatory species. The fatty acid composition of Epimeria georgiana shows no clear indication of a special feeding behaviour. The high level of 18:1(n-9) points to feeding on degraded material, such as crustacean remains; however, the small proportion of phytoplanktonic marker fatty acids present indicates feeding on material of planktonic origin.

$W$. obesa has the most obligate scavenging lifestyle of the amphipods studied (Arnaud 1970). It is a large amphipod with a wide circum-Antarctic distribution, occurring in subsurface waters and down to $900 \mathrm{~m}$ depth in the Weddell Sea (De Broyer and Klages 1990; De Broyer and Jazdzewski 1993). The main fraction of its digestive tract content was carrion-derived organic matter, which comes from necrophagous feeding on prey such as fish and invertebrate carcasses, and probably also on seal or penguin carrion (Dauby et al., in press). The exact share of the source cannot be precisely defined. The relatively high amount of triacylglycerols in the lipids indicates periods of starvation, where storage lipids may be important for survival. This finding is supported by feeding experiments that revealed that $W$. obesa is well adapted to long periods of starvation (Chapelle et al. 1994). Coleman (1991) reported that this species can endure periods of up to 18 months without feeding. The fatty acid composition of $W$. obesa is unique, since it is dominated to a great extent by $18: 1(n-9)$, which occurred in similar amounts of nearly $50 \%$ in phospholipids and triacylglycerols. Lipid-rich fish are potential food items, being known to contain high levels of 18:1(n-9) (Hagen et al. 2000) but not as high as found for $W$. obesa. It is noteworthy that the phospholipids were also dominated by 18:1(n-9), since phospholipids are normally considered to require high amounts of polyunsaturates for maintenance of membrane fluidity. There is also no evidence of an increased bacterial activity, since odd-chain, branched and hydroxy fatty acids were not detected. The small amount of additional organic material in the digestive tract of $W$. obesa might be influenced by diatomous components. However, due to the predominance of 18:1(n-9), no indication of food of phyto- or zooplanktonic origin can be obtained.

\section{Conclusions}

Lipids integrate feeding behaviour over long periods of time, whereas the digestive tract content showed us the recent food uptake. Combining the two methods, the amphipod species studied exhibited a lipid and digestive tract content pattern indicative of their typical life strategies and trophic niches. These are reflected by specific fatty acid compositions and food items, as shown for $O$. edentata feeding on macroalgae and for A. richardsoni, where fatty acid composition is probably dependent on sedimentation events of periodically occurring phytoplankton blooms. Conversely, less specific fatty acid compositions indicate opportunistic feeding on living or dead food items with similar fatty acid compositions. It is remarkable how amphipods can adapt their fatty acid composition to the nutritional conditions, not only in the storage lipids but also in the membrane lipids. The differences between the fatty acid compositions of the phospholipids as structural components of membranes and the triacylglycerols as storage lipids are small. We therefore propose that further investigations of trophic linkages of benthic amphipods should be done with analysis of the total lipid fatty acid composition. Future lipid investigations should consider reproductive strategies and seasonal variations, since there are clear indications that amphipods can shift their food items depending on season and food availability. Additional feeding experiments and analysis of the $\delta^{13} \mathrm{C}$ and $\delta^{15} \mathrm{~N}$ values could help clarify food-web interactions of benthic amphipods.

Acknowledgements We thank A. Ratje for technical assistance. The present research was partly carried out under the auspices of the Scientific Research Programme on Antarctic (Phase IV) from the Belgian State Prime Minister's Federal Office for Scientific, Technical and Cultural Affairs (OSTC contract no. A4/DD/B02). We thank R. Crawford and G. Kattner for their careful reading and constructive comments on the manuscript.

\section{References}

Ackman RG, Tocher CS, McLachlan J (1968) Marine phytoplankter fatty acids. J Fish Res Board Can 25:1603-1620

Albers CS, Kattner G, Hagen W (1996) The composition of wax esters, triacylglycerols and phospholipids in Arctic and Antarctic copepods: evidence of energetic adaptations. Mar Chem $55: 347-358$

Arnaud PM (1970) Frequency and ecological significance of necrophagy among the benthic species of Antarctic coastal waters. In: Holdgate MW (ed) Antarctic ecology, vol 1. Academic Press, London, pp 259-267

Arntz W, Gutt J (eds) (1999) The expedition ANTARKTIS XV/3 (EASIZ II) of RV Polarstern in 1998. Ber Polarforsch 301:1229

Carballeira NM, Reyes ED (1990) Novel very long chain fatty acids from the sponge Petrosia pellasarca. J Nat Prod Lloydia 53:836-840

Carballeira NM, Shalabi F (1995) The rare Caribbean sponge Leucosolenia canariensis: phospholipids and sterols. Lipids 30:467-470

Chapelle G, Peck LS, Clarke A (1994) Effects of feeding and starvation on the metabolic rate of the necrophagous Antarctic amphipod Waldeckia obesa (Chevreux 1915). J Exp Mar Biol Ecol 183:63-76

Coleman CO (1989a) On the nutrition of two Antarctic Acanthonotozomatidae (Crustacea: Amphipoda). Polar Biol 9:287-294 
Coleman CO (1989b) Burrowing, grooming and feeding behaviour of Paraceradocus, an Antarctic amphipod genus (Crustacea). Polar Biol 10:43-48

Coleman CO (1989c) Gnathiphimedia mandibularis K.H. Barnard 1930, an Antarctic amphipod (Acanthonotozomatidae, Crustacea) feeding on Bryozoa. Antarct Sci 1:343-344

Coleman CO (1990a) Two new Antarctic species of the genus Epimeria (Crustacea: Amphipoda: Paramphithoidae), with description of juveniles. J Soc N-Z 20:151-178

Coleman CO (1990b) Bathypanoploea schellenbergi Holman and Watling, 1983, an Antarctic amphipod (Crustacea) feeding on Holothuroidea. Ophelia 31:197-205

Coleman CO (1991) Comparative fore-gut morphology of Antarctic Amphipoda (Crustacea) adapted to different food sources. Hydrobiologia 223:1-9

Cripps GC, Hill HJ (1998) Changes in lipid composition of copepods and Euphausia superba associated with the diet and environmental conditions in the marginal ice zone, Bellingshausen Sea, Antarctica. Deep Sea Res I 45:1357-1381

Dauby P, Scailteur Y, De Broyer C (2001) Trophic diversity within eastern Weddell Sea amphipod community. Hydrobiologia 443:69-86

Dauby P, Scailteur Y, Chapelle G, De Broyer C (in press) Potential impact of the main benthic amphipod species populations on the eastern Weddell Sea shelf ecosystem (Antarctica). Polar Biol

De Broyer C, Jazdzewski K (1993) Contribution to the marine biodiversity inventory. A checklist of the Amphipoda (Crustacea) of the Southern Ocean. Doc Trav Inst R Sci Nat Belg 73:1-155

De Broyer C, Jazdzewski K (1996) Biodiversity of the Southern Ocean: towards a new synthesis for the Amphipoda (Crustacea). Boll Mus Civ Stor Nat Verona 20:547-568

De Broyer C, Klages M (1990) Studies on amphipod biology. In: Arntz W, Ernst W, Hempel I (eds) The expedition ANTARKTIS VII/4 (EPOS Leg 3 ) and VII/5 of the R/V Polarstern in 1989. Ber Polarforsch 68:113-115

Dembitsky VM, Rezanka T, Kashin AG (1994) Comparative study of the endemic freshwater fauna of lake Baikal. 6. Unusual fatty acid and lipid composition of the endemic sponge Lubomirskia baicalensis and its amphipod crustacean parasite Brandtia (Spinacanthus) parasitica. Comp Biochem Physiol 109B:415426

Fay L, Richli U (1991) Location of double bonds in polyunsaturated fatty acids by gas chromatography-mass spectrometry after 4,4-dimethyloxazoline derivatization. J Chromatogr 541:89-98

Fleurence J, Gutbier G, Mabeau S, Leray C (1994) Fatty acids from 11 marine macroalgae of the French Brittany coast. J Appl Phycol 6:527-532

Folch J, Lees M, Sloane-Stanley GH (1957) A simple method for the isolation and purification of total lipides from animal tissues. J Biol Chem 226:497-509

Fraser AJ, Tocher DR, Sargent JR (1985) Thin-layer chromatography-flame ionization detection and quantification of marine neutral lipids and phospholipids. J Exp Mar Biol Ecol 88:91-100

Graeve M (1993) Umsatz und Verteilung von Lipiden in arktischen marinen Organismen unter besonderer Berücksichtigung unterer trophischer Stufen. Ber Polarforsch 124:1-140

Graeve M, Hagen W, Kattner G (1994) Diet-induced changes in the fatty acid composition of Arctic herbivorous copepods: experimental evidence of trophic markers. J Exp Mar Biol Ecol 182:97-110

Graeve M, Kattner G, Piepenburg D (1997) Lipids in Arctic benthos: does fatty acid and alcohol composition reflect feeding and trophic interactions? Polar Biol 18:53-61

Hagen W (1988) Zur Bedeutung der Lipide im antarktischen Zooplankton. Ber Polarforsch 49:1-129

Hagen W, Kattner G, Friedrich C (2000) The lipid compositions of five Antarctic fish species with different life strategies. Polar Biol. 23:785-791

Harrington GW, Beach DH, Dunham JE, Holz GG (1970) The polyunsaturated fatty acids of dinoflagellates. J Protozool 17:213-219
Hynes HBN (1950) The food of the freshwater stickelbacks Gasterosteus aculeatus and Pygosteus pungitius, with a review of the methods used in studies of the food of fishes. J Anim Ecol 19:36-58

Kates K, Volcani BE (1966) Lipid components of diatoms. Biochim Biophys Acta 116:264-278

Kattner G, Fricke HSG (1986) Simple gas-liquid chromatographic method for the simultaneous determination of fatty acids and alcohols in wax esters of marine organisms. J Chromatogr 361:263-268

Kattner G, Hagen W (1995) Polar herbivorous copepods - different pathways in lipid biosynthesis. ICES J Mar Sci 52:329335

Kawashima H, Takeuchi I, Ohnishi M (1999) Fatty acid compositions of caprellid amphipod species (Crustacea) from Otsuchi and Mutsu Bays in northern Japan. J Jpn Oil Chem Soc 48:2327

Khotimchenko SV (1995) Uncommon 16:1(n-5) fatty acid from Dictyota dichotoma and fatty acids of some brown algae of Dictyotaceae. Phytochemistry 38:1411-1415

Klages M, Gutt J (1990a) Observations on the feeding behaviour of the Antarctic gammarid Eusirus perdentatus Chevreux, 1912 (Crustacea: Amphipoda) in aquaria. Polar Biol 10:359-364

Klages M, Gutt J (1990b) Comparative studies on the feeding behaviour of high Antarctic amphipods (Crustacea) in laboratory. Polar Biol 11:73-79

Lancelot C, Keller MD, Rousseau V, Smith WO Jr, Mathot S (1998) Autoecology of the marine haptophyte Phaeocystis sp. NATO ASI Ser 67:88-101

Nelson MM, Mooney BD, Nichols PD, Phleger CF (2001) Lipids of Antarctic Ocean amphipods: food chain interactions and the occurrence of novel biomarkers. Mar Chem 73:53-64

Nichols PD, Skerratt JH, Davidson A, Burton H, McMeekin TA (1991) Lipids of cultured Phaeocystis pouchetii: signatures for food-web, biogeochemical and environmental studies in Antarctica and the southern ocean. Phytochemistry 30:3209-3214

Olaso I, Rauschert M, De Broyer C (2000) Trophic ecology of the family Artetidraconidae (Pisces: Osteichthyes) and its impact on the eastern Weddell Sea benthic system. Mar Ecol Prog Ser 194:143-158

Oliver JS, Slattery PN (1985) Effects of crustacean predators on species composition and population structure of soft-bodied infauna from McMurdo Sound, Antarctica. Ophelia 24:155175

Phleger CF, Nichols PD, Virtue P (1998) Lipids and trophodynamics of Antarctic zooplankton. Lipids 32:1093-1100

Phleger CF, Nelson MM, Mooney B, Nichols PD (1999) Lipids of abducted Antarctic pteropods Spongiobranchaea australis, and their hyperiid amphipod host. Comp Biochem Physiol 124B:311-323

Phleger CF, Nelson MM, Mooney B, Nichols PD (2000) Lipids of Antarctic salps and their commensal hyperiis amphipods. Polar Biol 23:329-337

Reinhardt AB, Van Vleet ES (1986) Lipid composition of twentytwo species of Antarctic midwater zooplankton and fish. Mar Biol 91:149-159

Richardson MG (1977) The ecology (including physiological aspects) of selected Antarctic marine invertebrates associated with inshore macrophytes. PhD Thesis, University of Durham

Riebesell U (1993) Aggregation of Phaeocystis during phytoplankton spring blooms in the southern North Sea. Mar Ecol Prog Ser 96:281-289

Sargent JR, Henderson RJ (1986) Lipids. In: Corner EDS, O’Hara SCM (eds) The biological chemistry of marine copepods. Clarendon Press, Oxford, pp 59-108

Sargent JR, Whittle KJ (1981) Lipids and hydrocarbons in the marine food web. In: Longhurst A (ed) Analysis of marine ecosystems. Academic Press, London, pp 491-533

Slattery PN, Oliver JS (1986) Scavenging and other feeding habits of lysianassid amphipods (Orchomene spp.) from McMurdo Sound, Antarctica. Polar Biol 6:171-177 
Swadling KM, Nichols PD, Gibson JAE, Ritz DA (2000) Role of lipid in the life cycles of ice-dependent and ice-independent populations of the copepod Paralabidocera antarctica. Mar Ecol Prog Ser 208:171-182

Wassmann P (1994) Significance of sedimentation for the termination of Phaeocystis blooms. J Mar Syst 5:81-100
Weisse T, Tande K, Verity P, Hansen F, Gieskes W (1994) The trophic significance of Phaeocystis blooms. J Mar Syst 5:67-79

Williams MJ (1981) Methods for analysis of natural diets in portunid crabs (Crustacea: Decapoda: Portunidae). J Exp Mar Biol Ecol 52:103-113 